\title{
MISPLACED POPULIST RAGE: CONGRESSIONAL MISSTEPS WITH EXECUTIVE COMPENSATION LIMITATIONS IN THE BAILOUT LEGISLATION
}

\author{
Joseph Filloy*
}

The American people are angry about executive compensation, and rightfully so. Many of you cite this as a serious problem, and I agree. We must find a way to address this in legislation without undermining the effectiveness of the program.

-Former Secretary of the Treasury Henry Paulson testifying before the House Financial Services Committee $^{1}$

\begin{abstract}
Most of us sign on to do jobs and we do them best we can. ... [But] we're told that some of the most highly paid people in executive positions are different. They need extra money to be motivated!
\end{abstract}

-Rep. Barney Frank, Chairman of the House Financial Services Committee ${ }^{2}$

In business as in life, you don't get what you deserve, you get what you negotiate. -Dr. Chester Karrass ${ }^{3}$

Starting in the summer of 2008, the United States and most other economies of the world began to feel the effects of the subprime mortgage crisis. In response, the federal government enacted The Emergency Economic Stabilization Act of 2008 (EESA) and The American Recovery and Reinvestment Act of 2009 (ARRA) to help restore stability to the U.S. economy. ${ }^{4}$ Ultimately this legislation, commonly referred to as "the bailout

* Candidate for Juris Doctorate, University of Pittsburgh Law School, May 2010. Graduate, University of Michigan, 2006. I would like to thank Joel Davis, CPA, and Mason Pastore for their indispensable help and guidance. I would also like to thank the American punditocracy, the sine qua non of this note.

1. David Stout, Paulson Gives Way on C.E.O. Pay, N.Y. Times, Sept. 24, 2008, http:// www.nytimes.com/2008/09/25/business/economy/25cong.html?hp.

2. Frank Bass \& Rita Beamish, AP Study Finds 1.6B Went to Bailed Out Bank Execs, HufFINGTON Post, Dec. 21, 2008, http://www.huffingtonpost.com/2008/12/21/ap-study-finds-16b-went-t_n_ 152647.html.

3. See generally Dr. Chester KarRass, In Business as In Life, You Don't Get What You Deserve, You Get What You Negotiate (1996).

4. Emergency Economic Stabilization Act of 2008, Pub. L. No. 110-343, 122 Stat. 3765 (2008); 
bill(s)," would result in substantial outlays of taxpayer money to financial institutions deemed systemically significant, or "too big to fail.".

In March 2009, the American public became aware that "bailed out" institutions would be making large bonus payments to their executives and employees. A groundswell of populist outrage erupted. ${ }^{6}$ Indignation over compensation became so emphatic that employees of bailed-out institutions received death threats, and bailed-out corporations were forced to hire armed guards to protect their office buildings. ${ }^{7}$ One group of outraged citizens organized a bus tour stopping at AIG executives' homes to ensure AIG executives would hear their protests. ${ }^{8}$

Politicians were quick to jump on the populist bandwagon. Any politician worth her mettle must possess the ability to recognize which way the winds of popular sentiment are blowing and adjust accordingly. Their professional duty is to represent their constituencies. Because their constituents were outraged over the bonus payments, the politicians' response was only natural. Members of Congress publicly lambasted bonus compensation payments. ${ }^{9}$ President Obama insisted that such compensation should not be tolerated. ${ }^{10}$ The House of Representatives swiftly passed H.R. 1542, a bill that proposed a $90 \%$ tax on bonus compensation made by bailout recipients. ${ }^{11}$

Despite their reactionary criticisms, members of Congress had recognized the potential for abusive bonus in the bailout legislation's gestation period. Some members voiced their desire for strict compensation limitations for corporations receiving federal funds; however, they faced opposition for their

American Recovery and Reinvestment Act of 2009, Pub. L. 111-5, § 7001, 123 Stat. 115, 516-20 (2009).

5. Government accountability Office, Troubled Asset Relief Program: Status of EFFORTS TO ADDRESS TRANSPARENCY AND ACCOUNTABILITY ISSUES (Jan. 2009), http://www.gao.gov/ new.items/d09296.pdf [hereinafter GOVERNMENT ACCOUNTABILITY OFFICE].

6. Arthur Delaney, Bailout Bonus Rage Hits the Streets, Huffington Post, Apr. 2, 2009, http://www.huffingtonpost.com/2009/03/19/bailout-bonus-rage-hits-t_n_176977.html.

7. Tom Baldwin \& Christine Seib, Armed Guards at AIG Offices After Death Threats over Bonuses, TIMES (London), Mar. 18, 2009, at 51, available at http://business.timesonline.co.uk/tol/ business/industry_sectors/banking_and_finance/article5927610.ece.

8. Michael Daly, AIG Executives' Homes on Display During Working Families Party Bus Tour, N.Y. DAILY NEws, Mar. 21, 2009, http://www.nydailynews.com/money/2009/03/22/2009-03-22_aig executives_homes_on_display_during_w.html.

9. Bonus Furor May Prompt Limits on AIG Bailout, Associated Press, Mar. 17, 2009, http://www.msnbc.msn.com/id/29714402.

10. Sandra Maler, Obama: AIG Bonus Bill "Rightly Reflects" Outrage, ReUTERS, Mar. 19, 2009, http://www.reuters.com/article/politicsNews/idUSTRE52I81820090319.

11. Shailagh Murray et al., Congress Moves to Slap Heavy Tax on Bonuses, WASH. Post, Mar. 20, 2009, at A01, available at http://www.washingtonpost.com/wp-dyn/content/article/2009/03/19/ AR2009031901542.html; H.R. 1542, 111 th Cong. (2009). 
stance on executive compensation. ${ }^{12}$ President George W. Bush's Administration, in particular Secretary of the Treasury Henry Paulson, opposed stringent regulation of executive wages. ${ }^{13}$ Secretary Paulson argued that if significant limitations on executive pay were tied to federal aid, firms would refuse to participate in aid program, thereby damaging the efficacy of the stabilization plan. ${ }^{14}$

Because of the political wrangling during the passage of EESA, little progress was made in the battle to curb excessive executive compensation. Nevertheless, proponents of regulating executive compensation were able to make significant changes to how corporations compensated their executives with the ARRA. The purpose of this Note is to explore the political negotiations surrounding the passage of the EESA and ARRA, with the aim of addressing whether opponents of executive compensation regulation had a legitimate claim during the negotiations surrounding the EESA. Specifically, could a corporate board of directors refuse federal aid because of the limitations placed on executive pay? A second purpose of the Note is to examine the legislative decision to address excessiveness in executive compensation and the need to stabilize the economy in the same bill. This Note argues that by packaging its solutions to these two distinct problems together, Congress hindered its ability to resolve each problem effectively. In Part I of this Note, I will survey the political and economic landscape surrounding the passage of EESA and ARRA. In Part II, I will discuss the limitations placed on executive pay by the EESA and the subsequent amendments in ARRA. Part III discusses potential ramifications of a board of directors' decision to reject federal aid because of the limitations placed on executive pay. Part IV concludes the Note with a discussion of congressional effectiveness.

12. David M. Herszenhorn et al., Democrats Set Terms as Bailout Debate Begins, N.Y. TIMES, Sept. 21, 2008, at A1, available at http://www.nytimes.com/2008/09/22/business/22paulson.html.

13. Andrew Clark \& Elana Schor, Paulson Under Pressure to Toughen Bailout Plan, GuARDIAN, Sept. 24, 2008, at 24, available at $\mathrm{http}$ ://www.guardian.co.uk/business/2008/sep/24/wallstreet.georgebush.

14. Stout, supra note 1. 


\section{PART I-ECONOMIC AND POLITICAL BACKDROP BEHIND THE PASSAGE OF EESA AND ARRA}

I believe if the credit markets are not functioning, that jobs will be lost, the unemployment rate will rise, more houses will be foreclosed upon, GDP will contract, that the economy will just not be able to recover in a normal, healthy way, no matter what other policies are taken.

\section{- Chairman of the Federal Reserve Ben Bernanke ${ }^{15}$}

And we need a rescue plan. This is-it's hard work. Our proposal is a big proposal. And the reason it's big and substantial is because we got a big problem ... [t] here are disagreements over aspects of the rescue plan, but there is no disagreement that something substantial must be done.

$$
\text { -President George W. Bush }{ }^{16}
$$

I don't think a single call to my office on this proposal has been positive.

$$
\text { - Sen. Sherrod Brown (D-Ohio) }{ }^{17}
$$

The subprime mortgage crisis loomed over the global economy during the summer of 2008. ${ }^{18}$ Pundits, politicians and journalists could see the precipice approach, but no one could predict the calamitous results of the eventual meltdown. On September 16, following its decision to takeover mortgage giants Fannie Mae and Freddie Mac, the Treasury Department and Federal Reserve announced the rescue of one of the world's largest insurers, American International Group (AIG). ${ }^{19}$ Meanwhile, the same agencies allowed the venerable investment bank Lehman Brothers to fail. ${ }^{20}$

The following day the Dow Jones Industrial Average (DJIA) closed 450 points lower than its previous close. ${ }^{21}$ In the subsequent three weeks, the DJIA would take a precipitous fall, flying past the 10,000 point mark, finally meeting some resistance at 8,451 points, forty percent down from its all time

15. David Rogers, Bush to Address Nation Tonight as Opposition to Bailout Plan Builds, Politico, Sept. 24, 2008, http://www.politico.com/news/stories/0908/13816.html.

16. Press Release, President George W. Bush, President Bush Discusses Negotiations to Finalize Legislation on the Financial Rescue Package (Sept. 26, 2008), available at http:/georgewbushwhitehouse.archives.gov/news/releases/2008/09/20080926.html [hereinafter Bush Press Release].

17. Rogers, supra note 15.

18. Credit crisis could cost nearly $\$ 1$ trillion, IMF predicts, N.Y. TIMES, Apr. 8, 2008, available at http://www.nytimes.com/2008/04/08/business/worldbusiness/08iht-imf.3.11771908.html.

19. Glenn Kessler \& David S. Hilzenrath, Stocks Plunge as Crisis Intensifies, WASH. Post, Sept. 16, 2008, at A1, available at http://www.washingtonpost.com/wp-dyn/content/story/2008/09/14/ST200 8091402574.html.

20. Id.

21. Google Finance, http://finance.google.com (follow "Dow" hyperlink). 
high reached a year before on October 12, 2007, almost one year to the date. ${ }^{22}$ The S\&P 500 lost nearly a quarter of its total value during the same three weeks. ${ }^{23}$ Every world market felt similar declines, including a twenty-plus percent drop in the Russian RTS, prompting the index to suspend trading indefinitely. ${ }^{24}$

Market shocks of this magnitude had not occurred or manifested since the Great Depression. Accumulated wealth simply vanished. Americans were lucky if their retirement funds, typically heavy on securities, retained half of their pre-shock values. ${ }^{25}$ Irresponsible borrowing and lending, coupled with the securitization of risk, created an environment of great uncertainty. When the market for toxic subprime debt disappeared, banks that had securitized the debt and held it as assets on their balance sheets were forced to take colossal write-offs. ${ }^{26}$

While the markets plummeted, uncertainty surged. Credit markets began to freeze as banks unsure about the strength of their holdings and crippled by write-offs became reluctant to loan what little capital they had left. ${ }^{27}$ The credit freeze allowed problems for the banks to ripple throughout the economy ${ }^{28}$ Before the shock, a constant flow of credit allowed corporations to rely on short-term debt for working capital. ${ }^{29}$ Once lending started to dry up, corporations that had become dependent on commercial paper markets struggled to secure the money necessary to make payroll and cover overhead. ${ }^{30}$ Concurrently, consumers stopped spending. ${ }^{31}$ Lacking customers for revenue or the ability to obtain credit, businesses were forced to lay off hundreds of thousands of workers. ${ }^{32}$ As unemployment doubled, and spending continued

22. Google Finance, http://finance.google.com (follow "Dow" hyperlink).

23. Google Finance, http://finance.google.com (follow "S\&P 500" hyperlink).

24. Asia, Pacific Market Tumble in Opening, CNN, Oct. 6, 2008, http://edition.cnn.com/2008/ BUSINESS/10/06/stock.markets/index.html.

25. Timeline: Sub-Prime Losses, BBC, May 19, 2008, http://news.bbc.co.uk/2/hi/business/ 7096845.stm

26. $I d$.

27. Paul Krugman, Moment of Truth, N.Y. TIMES, Oct. 9, 2008, at A33, available at http://www.nytimes.com/2008/10/10/opinion/10krugman.html.

28. Id.

29. Dennis K. Berman, Market's Got You Worried? Just Watch for the Layoffs, WaLl ST. J., Sept. 30, 2008, at C1, available at http://online.wsj.com/article/SB122273610947888639.html.

30. Id.

31. Paul Krugman, When Consumers Capitulate, N.Y. TimES, Oct. 31, 2009, at A31, available at http://www.nytimes.com/2008/10/31/opinion/31 krugman.html.

32. See Berman, supra note 29. 
to slow, Americans began to wonder if the economic downturn would ever hit bottom. ${ }^{33}$

\section{The Man with the Plan}

Meanwhile Congress, the Treasury, the Federal Reserve, and President Bush scrambled to keep the sinking ship afloat. After a primetime nationwide address, Treasury Secretary Henry Paulson submitted a proposal for governmental action in response to the various crises. Published on September 20, 2009, the three-page proposal was remarkably thin on details and entirely devoid of oversight. In fact, the Paulson proposal requested the authority to purchase $\$ 700,000,000$ in assets while asserting all transactions would be "non-reviewable . . by any court of law." "34

Three days later, Secretary Paulson and Federal Reserve Chairmen Ben Bernanke presented the three-page proposal to the Senate Banking Committee. The Committee categorically rejected the proposal. ${ }^{35}$ Committee Chairman Senator Christopher Dodd chastised the proposal as "stunning and unprecedented in its scope and lack of detail." ${ }^{\text {36 }}$

To address the crisis, the Bush Administration planned to increase capital in the banking system. ${ }^{37}$ The Administration had faith that by providing banks with capital, banks would be more likely to make loans, which in turn would unfreeze the credit markets and return the economy to normalcy. ${ }^{38}$

The plan targeted nine of the nation's largest financial institutions for the first injections of capital. These nine institutions held 55 percent of the United State's banking assets and were considered "systemically significant to the operation of the financial system." 39 In order to minimize risk to taxpayers,

33. Bureau of Labor Statistics, Labor Force Statistics, http://www.bls.gov/data/\#unemployment (follow Labor Force Unemployment Rate hyperlink) (last visited Mar. 15, 2009).

34. Text of Draft Proposal for Bailout Plan, N.Y. Times, Sept. 20, 2008, available at http:// www.nytimes.com/2008/09/21/business/21draftcnd.html?ref=business.

35. Mark Landler \& Steven Lee Myers, Buyout Plan for Wall Street Is a Hard Sell on Capitol Hill, N.Y. TIMES, Sept. 23, 2008, available at http://www.nytimes.com/2008/09/24/business/economy/ 24 fannie.html.

36. Id.

37. Turmoil in US Credit Markets: Recent Actions Regarding Government Sponsored Entities, Investment Banks and other Financial Institutions: Hearing Before the S. Comm. on Banking, Housing, \& Urban Affairs, 110th Cong. (2008) (statement of Secretary Henry M. Paulson, Jr.).

38. Department of the Treasury, Responses to Questions of the First Report of the CONGResSional OVERSight PANEL FOR ECONOMiC StABILIZATION (2008), http://www.treas.gov/ press/releases/reports/123108\%20cop\%20response.pdf

39. GOVERNMENT ACCOUNTABILITY OfFICE, supra note 5, at 13. 
only healthy, viable, institutions would be eligible for funding. ${ }^{40}$ Because the Administration considered the institutions healthy, their participation in the program would be voluntary. ${ }^{41}$

In the weeks that would follow, the House and Senate fattened the Paulson/Bernanke plan into acceptable legislation. The process was arduous. At times it appeared as though negotiations might unravel creating catastrophic government action unseen since Hurricane Katrina. As concern over that possibility mounted, President Bush was forced to step in; he called a press conference to assure the American people failure to act would not be tolerated. ${ }^{42}$ Congress ultimately capitulated bringing the Administration's bank capitalization program to life with the Emergency Economic Stabilization Act (EESA). ${ }^{43}$

\section{Executive Compensation Throws a Wrench in the Works}

Executive compensation became a major sticking point. Criticism of executive compensation packages has been pervasive in the American political and corporate landscapes for the better part of the past two decades. As the United States economy turned the corner on the stagflation of the 1970s, corporations realized greater profits. Significant increases in the overall compensation for executives accompanied these corporate gains. In 1978 the average chief executive officer (CEO)'s compensation was thirty-five times more than that of the average worker. By 2005 that ratio swelled to 262 times the size of the average worker's pay. ${ }^{44}$ Between 1991 and 2001, CEO compensation grew by a rate of nearly $340 \%,{ }^{45}$ while growth in employee wages was relatively stagnant over the same period. ${ }^{46}$

Secretary Paulson, former CEO of the investment bank Goldman Sachs, argued that limitations on executive pay would negatively affect participation

\footnotetext{
40. Id.

41. Id. at 3,10 .

42. Bush Press Release, supra note 16.

43. Emergency Economic Stabilization Act of 2008, Pub. L. No. 110-343, 122 Stat. 3765 (2008).

44. Lawrence Mishel, CEO-to-Worker Pay Imbalance Grows, Economic Policy Institute, http://www.epi.org/economic_snapshots/entry/webfeatures_snapshots_20060621.

45. Michael B. Dorff, Softening Pharaoh's Heart: Harnessing Altruistic Theory and Behavioral Law and Economics to Rein in Executive Salaries, 51 BuFF. L. REV. 811, 813 (2003).

46. For example, during the period from 2002-2007, the growth rate of the average annual wage was 0.0\%. LAWRENCE MisHel ET AL., THE STATE OF WORKING AMERICA 2008/2009 (2009), available at http://www.stateofworkingamerica.org/tabfig/2008/03/SWA08_Wages_Table.3.2.pdf.
} 
in the stabilization program. ${ }^{47}$ Paulson went on record saying, "Let's talk about executive salaries. There have been excesses there. I agree with the American people. Pay should be for performance, not for failure. But we need this system to work, and so we- the reforms need to come afterwards." 48

Many members of Congress expressed a different perspective. They viewed the bailout legislation as an appropriate vehicle to address the perceived excesses in executive compensation. ${ }^{49}$ In the years prior to the subprime meltdown, large executive bonuses on Wall Street became commonplace. Bonuses for Wall Street firms totaled $\$ 33.2$ billion in 2007; seven of the largest investment firms increased executive compensation to $\$ 122$ billion, a 10\% increase over 2006 wages, despite collectively recording $\$ 55$ billion in losses and $\$ 200$ billion in cumulative losses to shareholder value. ${ }^{50}$ Four of those seven firms would receive bailout funds - Goldman Sachs, JP Morgan Chase, Citigroup, and Merrill Lynch; two would be acquired by other firms receiving federal funds-BearStearns and Morgan Stanley; and one-Lehman Brothers, would fold. ${ }^{51}$

Support for limiting compensation came from both sides of the aisle. Representative Barney Frank, Democrat and ranking member of the House Financial Services Committee, put forth a proposal which would give the Treasury the authority to set "appropriate standards" for executive compensation for firms receiving bailout funding. ${ }^{52}$ The proposal also included a provision giving corporations the authority to "claw-back" compensation payments already made. ${ }^{53}$ Republican presidential candidate Senator John McCain called for a strict cap on executive compensation at a level of $\$ 400,000$, the same wage paid to the President of the United States. ${ }^{54}$

47. James Politi et al., Wrangle on US Rescue Oversight Intensifies, FIN. TIMES, Sept. 22, 2008, http://www.ft.com/cms/s/0/eeffd8e8-88d3-11dd-a179-0000779fd18c.html.

48. Herszenhorn et al., supra note 12.

49. House Speaker Nancy Pelosi said that the administration's proposal did "not include the necessary safeguards. Democrats believe a responsible solution should include ... constraints on excessive executive compensation." Id.

50. Tomoeh Murakami Tse \& Renae Merle, The Bonuses Keep Coming, WASH. Post, Jan. 29, 2008, at D01, available at http://www.washingtonpost.com/wp-dyn/content/story/2008/01/29/ST20080 12900465.html.

51. Morgan Stanley News, N.Y. TIMES, available at http://topics.nytimes.com/top/news/business/ companies/morgan_stanley/index.html (last visited Mar. 15, 2009).

52. Ron Chernow, Op-Ed, The Lost Tycoons, N.Y. TIMES, Sept. 27, 2008, at WK12, available at http://www.nytimes.com/2008/09/28/opinion/28chernow.html.

53. Id.

54. Politi et al., supra note 47. 
Fearful that the bailout would save Wall Street and not Main Street, Democratic presidential candidate Barack Obama summed up the sentiment of many Americans when he stated, "Taxpayers shouldn't be spending a dime to reward CEOs on Wall Street while they're going out the door." ${ }^{\text {5 }}$ Instead of having their taxes spent on economic recovery and increasing liquidity, Americans feared corporations would use bailout funds to compensate the same executives and managers they considered responsible for the crisis. ${ }^{56}$

If at First You Don't Succeed . . .

As I will discuss in detail in Part II, the limitations on executive compensation found in the final version of EESA were ultimately nominal. As of December 21, 2008, 116 financial intuitions had received \$188 billion from the Troubled Assets Relief Program (TARP) authorized by EESA.$^{57}$ Despite regulations on executive pay, top executives' compensation at these firms receiving bailout funds collectively totaled $\$ 1.6$ billion. ${ }^{58}$

The American public responded to the bailout with mixed opinions, ranging from great antipathy to complete skepticism. Protestors marched in many major American cities. ${ }^{59}$ One poll noted only 28\% of Americans supported the bailout. ${ }^{60}$ Congress recognized the need for more legislation. Following the election of Barack Obama, Congress immediately got to work on the second piece of bailout legislation, the American Recovery and Reinvestment Act (AARA). ${ }^{61}$

On February 4, while the ARRA was making its way through the Senate, President Obama released his proposal for executive compensation

55. Dan Balz \& Robert Barnes, Obama Urges Action Wall Street-and for Main Street, Too, WASH. Post, Sept. 21, 2008, http://voices.washingtonpost.com/the-trail/2008/09/21/obama_urges_action_for_ wall_st.html.

56. Matthew Benjamin, Americans Oppose Bailouts, Favor Obama to Handle Market Crisis (Sept. 24, 2008), http://www.bloomberg.com/apps/news?pid=20601087\&sid=aYK_5_ fV5D4M\&refer=home.

57. Bass \& Beamish, supra note 2.

58. Id.

59. Ken Bensinger, Public Isn't Buying Wall Street Bailout, L.A. TIMES, Sept. 26, 2008, available at http://www.latimes.com/business/la-fi-voxpop26-2008sep26,0,3246836.story.

60. RASMUSSEN REPORTS, Only 28\% Support Federal Bailout Plan, Sept. 22, 2008, available at http://www.rasmussenreports.com/public_content/business/federal_bailout/only_28_support_federal_ba ilout_plan.

61. American Recovery and Reinvestment Act of 2009, Pub. L. 111-5, § 7001, 123 Stat. 115, 516-20 (2009). 
regulation. ${ }^{62}$ President Obama broadcasted his concerns, "For top executives to award themselves these kinds of compensation packages in the midst of this economic crisis is not only in bad taste-it's a bad strategy-and I will not tolerate it." ${ }^{\prime 63}$ The President's plan proposed capping executive compensation at $\$ 500,000 .{ }^{64}$ Additionally, incentive-based bonus payments would be confined to grants of stock options, redeemable only after all corporate obligations to the government were repaid. ${ }^{65}$

The week after President Obama released his proposal for executive compensation, the House Financial Services Committee, poised to get tough on executive compensation, called on the heads of the nine "systemically significant" financial institutions to testify about the first round of the bailout. ${ }^{66}$ Citing public anger over the perceived failures of the bailout, Committee members preceded to brow beat these CEOs for, among other things, extraordinary salaries, lavishly refurbishing already exquisite offices, and ownership of vacation homes. ${ }^{67}$ One CEO, Vikram Pandit of Citigroup, pledged to cut his own salary to one dollar until Citigroup returned to profitability. ${ }^{68}$

Although Congress dropped President Obama's request for a strict cap on compensation from the final bill, the ARRA made substantial amendments to the executive compensation regulations of EESA. ${ }^{69}$ Because the reforms on executive pay apply to any business with an outstanding obligation arising from participation in TARP, institutions which voluntarily agreed to

62. Press Release, Office of the Press Sec'y, Remarks by President Barack Obama on Executive Compensation with Secretary Geithner (Feb. 4, 2009), available at http://www.whitehouse.gov/ the_press_office/RemarksbyPresidentBarackObamaOnExecutiveCompensationSecretaryGeithner/.

63. $I d$.

64. $I d$.

65. Id.

66. Louise Story, Ire but No Brimstone for Top Bankers at Hearing, N.Y. TIMES, Feb. 12, 2009, at B1, available at http://www.nytimes.com/2009/02/12/business/12bank.html?_r=1\&pagewanted= 2\&n=Top/Reference/Times\%20Topics/People/S/Story,\%20Louise.

67. See generally TARP Accountability: Use of Federal Assistance by the First TARP Recipients, http://www.house.gov/apps/list/hearing/financialsvcs_dem/hr021109.shtml (providing transcripts and records of the hearing) (last visited Mar. 15, 2009).

68. Story, supra note 66 , at B8.

69. See, e.g., Tomoeh Murakami Tse, Congress Trumps Obama by Cuffing Bonuses for CEOs, WASH. POST, Feb. 14, 2009, at A1, available at http://www.washingtonpost.com/wp-dyn/content/ article/2009/02/13/AR2009021303288.html?hpid=topnews\&sid=ST2009021302017 ("Congress missed a huge opportunity to set a strict and measurable limit on executive pay. I'm afraid companies will find ways to shift compensation to other pots and continue to make massive payouts that have so outraged the American people."). 
participate under the executive compensation rules of EESA are now subject to the heightened restrictions of ARRA.

\section{PART II-LIMITATIONS SET ON EXECUTIVE COMPENSATION BY EESA AND ARRA}

\section{Round One: The Emergency Economic Stabilization Act of 2008}

President George W. Bush signed the final version of EESA ${ }^{70}$ into law on October 3, 2008. ${ }^{71}$ Section 111 of the bill, entitled "Executive Compensation and Corporate Governance" contains the bulk of limitations placed on executive compensation. ${ }^{72}$ It provides limitations on pay deemed excessive, prohibits incentives that encourage unnecessary risk taking, and forbids golden parachute payouts to executives of financial institutions that receive bailout funds. ${ }^{73}$ In spite of the bellicose public discourse about the need to control executive compensation, the final provisions of the bill failed to rein in the perceived excesses of executive compensation.

First, limitations on executive pay apply only to firms who received TARP assistance. ${ }^{74}$ The Secretary of the Treasury uses TARP funds to promote market stability by purchasing troubled assets, such as mortgage backed securities, in exchange for non-voting preferred stock and warrants for common stock from participating corporations. ${ }^{75}$ These sales create corporate obligations to the United States government, and corporations are subject to the limitations so long as the obligations are outstanding. As of March 10, 2009 , almost 400 institutions have participated in the program by selling assets to the U.S. government. ${ }^{76}$

70. Emergency Economic Stabilization Act of 2008, Pub. L. No. 110-343, 122 Stat. 3765 (2008).

71. Press Release, Office of the Press Sec'y, President Bush Signs HR 1424 Into Law (Oct. 2, 2008), http://georgewbush-whitehouse.archives.gov/news/releases/2008/10/20081003-17.html.

72. Emergency Economic Stabilization Act of 2008, Pub. L. No. 110-343, 122 Stat. 3765 (2008).

73. Emergency Economic Stabilization Act of 2008, 12 U.S.C.A. § 5221 (Supp. III 2009).

74. 12 U.S.C.A. § 5221(a).

75. See Congressional Budget Office, The Troubled Assets Relief Program: Report on Transactions Through DeCEMBER 31, 2008 (2009), available at http://www.cbo.gov/ftpdocs/ 99xx/doc9961/01-16-TARP.pdf.

76. DeP'T OF THE TREASURy, OfFice of FinanCial Stability, Troubled AsSet Relief Program: TRANSACTIONS REPORT FOR PERIOD ENDING MARCh 6, 2009, available at http://www.ustreas.gov/ initiatives/eesa/docs/transaction_report_03-10-09.pdf. 


\section{Limitations That Satisfy “Appropriate Standards”}

In order to receive assistance, corporations participating in TARP must sign an agreement stating they will obey the limitations on executive pay promulgated by section 111 and the Treasury Department. ${ }^{77}$ In section 111, Congress delegated the burden to set limitations, or "appropriate standards" for executives' compensation, ${ }^{78}$ to the Treasury Department. The assignment was not entirely lacking direction; Congress mandated that the Treasury's standards satisfy certain criteria.

The limitations must exclude forms of incentive-based compensation that encourage senior executive officers (SEOs) to take unnecessary risk. ${ }^{79}$ A "senior executive officer" is defined as any of the top five "highly paid executives" whose compensation must be reported to the Securities and Exchange Commission pursuant to the Securities Exchange Act of $1934 .^{80}$ "Unnecessary risk" is not defined.

\section{Compensation Committees}

Under the regulations the Treasury Department promulgated, corporate boards must appoint independent compensation committees in order to prevent compensation that encourages unnecessary risk. ${ }^{81}$ These committees must review the contracts of SEOs with company risk officers to ensure that "SEO incentive compensation arrangements do not encourage SEOs to take unnecessary and excessive risks that threaten the value of the TARP recipient." ${ }^{82}$ In order to comply, the committee should identify any short-term or long-term risks the contracts may encourage, and then proceed to limit compensation so that SEOs are not "encouraged to take [such] risks." 83 Also, the committee must certify to the Treasury that the committee complied with all review requirements, and "must provide an explanation of how their senior executive compensation arrangements do not encourage excessive and

77. See generally U.S. Department of the Treasury, Road to Stability Capital Purchase Program, http://www.ustreas.gov/initiatives/eesa/agreements/index.shtml (providing a collection of TARP agreements) (last visited Mar. 15, 2009).

78. 12 U.S.C.A. § 5221(b)(1) (Supp. 2009).

79. Id. 12 U.S.C.A. $\S 5221(\mathrm{~b})(2)(\mathrm{A})$.

80. 12 U.S.C. § 5221(b)(3). See also 17 C.F.R. § 229.402(a)(3) (2008) (providing regulations promulgated by SEC).

81. 31 C.F.R. § 30.4(a) (2009).

82. 31 C.F.R. $\$ 30.4(a)(1)$.

83. 31 C.F.R. $\S 30.4(a)(4)$. 
unnecessary risk-taking. ${ }^{" 84}$ Committees must review SEO contracts annually while corporate TARP obligations remain outstanding. ${ }^{85}$

Although these regulations on their face appear to place heavy burdens on participating institutions, in practice, institutions would likely have to make few changes. First, in order to receive the deduction for performance-based pay allowed under section 162 of the Tax Code, corporations must already have independent compensation committees established to certify that performance goals have been met and a majority of shareholders voted to approve the terms and payment of the performance-based remuneration. ${ }^{86}$ Moreover, any company that is publicly traded on the NASDAQ or the NYSE must have an independent compensation committee review executive compensation. ${ }^{87}$ All of the nine "systemically significant" financial institutions are publicly traded on either the NASDAQ or the NYSE. ${ }^{88}$

\section{Claw-backs}

The "appropriate standards" must also include a provision that allows for the claw-back of any bonus compensation payments made to SEOs based on financial reports later found to be inaccurate. ${ }^{89}$ This provision is similar to Sarbanes-Oxley Act section 304, which provides for the disgorgement of bonus payments or profits made on securities sales of CEOs and CFOs. ${ }^{90}$ However, unlike section 304, there is not a limited recovery period. The provision applies to inaccuracies in both accounting and performance metrics, and claw-back is required whenever a material inaccuracy is found. ${ }^{91}$ Nevertheless, this provision in no way limits executives' compensation

84. Press Release, U.S. Dep't of Treasury, Treasury Announces New Restrictions on Executive Compensation (Feb. 4, 2009), available at http://www.ustreas.gov/press/releases/tg15.htm.

85. 31 C.F.R. § 30.3(a)(2), (b) (effective Oct. 20, 2008 to June 14, 2009).

86. 26 U.S.C.A. $\S 162(\mathrm{~m})(4)(\mathrm{C})(2009)$.

87. See NASDAQ, Inc., Corporate Governance Rule 4350(c) (Apr. 15, 2004), available at http://www.nasdaq.com/about/CorporateGovernance.pdf, and NYSE, Inc., Listed Company Manual $\S$ 303A.05, available at http://nysemanual.nyse.com/LCM/Sections/. See also NASDAQ Corporate Governance: Summary of Rules Changes (Nov. 2003), available at http://www.nasdaq.com/ about/CorpGovSummary.pdf ("Independent director approval of CEO compensation is required, either by an independent compensation committee or by a majority of the independent directors meeting in executive session.”) (last visited Mar. 15, 2009).

88. GOVERNMENT ACCOUNTABILITY OfFICE, supra note 5.

89. 12 U.S.C.A. § 5221(b)(2)(B) (Supp. 2009).

90. 15 U.S.C.A. $\S 7243$ (Supp. 2009).

91. 15 U.S.C.A. $\$ 7243$. 
packages; it merely provides a means for corporations to recover compensation payments that should not have been made.

\section{Golden Parachutes}

The final Treasury limitation is a provision prohibiting the payment of golden parachute payments. ${ }^{92}$ Golden parachute payments are large payments made in connection with the termination of an executive's employment. ${ }^{93}$ These types of payments were a major talking point in the discourse surrounding the bailout negotiations. ${ }^{94}$ Although, on its face, the provision prevents employers from making golden parachute payments, the section (d) sunset provision provides a large loophole which renders the parachute prohibition ineffectual. ${ }^{95}$ Section (d) permits payments on golden parachute clauses that were contracted for prior to the corporate receipt of TARP funds. ${ }^{96}$ A corporation need only to negotiate any golden parachute clauses before participating in TARP to work around the parachute proscription of section $(b)(2)(C)$.

In addition to the regulations of section 111, section 302 amends the limitation on salary deductions permitted under section 162 of the Tax Code. ${ }^{97}$ Under the amended version, firms participating in TARP are limited to a $\$ 500,000$ rather than a $\$ 1$ million deduction for executive salaries. ${ }^{98}$

As noted earlier, these provisions were ultimately ineffective in curbing excessive compensation. Wall Street bonuses for 2008 exceeded $\$ 18$ billion; and firms receiving TARP funds paid out $\$ 1.6$ billion in compensation. ${ }^{99}$

92. 12 U.S.C.A. 5221(b)(2)(C) (Supp. 2009).

93. See TARP Standards for Compensation and Corporate Governance, 74 Fed. Reg. 113, 28,141 (June 15, 2009) (to be codified at 31 C.F.R. § 30.9).

94. Chris Isidore, Golden Parachutes Here to Stay, CNN, Sept. 29, 2008, http://money.cnn.com/ 2008/09/28/news/economy/goldent_parachutes/index.htm.

95. Id.

96. 12 U.S.C.A. § 5221(d) (Supp. 2009).

97. Emergency Economic Stabilization Act of 2008, Pub. L. No. 110-343, § 302, 122 Stat. 3765, 3803-06 (2008).

98. I.R.C. § $162(\mathrm{~m})(5)$ (Supp. 2009).

99. Bass \& Beamish, supra note 2; Ross Colvin, Obama: Big Wall Street Bonuses Outrageous, REUTERS, Jan. 29, 2009, http://www.reuters.com/article/ousiv/idUSWAT01087820090129. 
Round Two: The American Recovery and Reinvestment Act of 2009

The ARRA provisions targeted at reining in excessive executive pay are located in Title VII, "Limits on Executive Compensation." 100 Working within the framework of the first bailout bill, Congress made significant amendments to the controls on executive pay. With some of the amendments, Congress took matters into its own hands by enacting express restrictions on pay. Although these restrictions are meaningful, of more consequence is Congress's decision to grant the Executive its own authority to limit executive compensation.

\section{Amending Section 111}

In the ARRA, Congress opted to amend the "appropriate standards" of the EESA's section 111. The amendments are applicable to any company, public or private, that has received or seeks to receive funds from the Troubled Asset Relief Program(TARP) established by the Emergency Economic Stabilization Act of 2008. ${ }^{101}$ Similar to original section 111, section (b)(3)(B) provides for recovery of any bonus or incentive payments made on the basis of financial statements found to be materially inaccurate. ${ }^{102}$ However, the scope of this provision was expanded so that it applies to any "senior executive officer and any of the next 20 most highly compensated employees" in firms that received TARP funding. ${ }^{103}$

Section (b)(3)(C) addresses the aforementioned weakness of the golden parachute sunset provision in section (d) of EESA. Under the modified provision, firms who receive TARP aid may not make golden parachute payments to senior executives, and the next five most highly compensated employees while any obligations arising from TARP assistance remain outstanding. ${ }^{104}$

The ARRA retains TARP recipients' obligation to establish "Independent Compensation Committees." ${ }^{105}$ In each fiscal year, TARP recipients must provide the Treasury with a narrative describing how each affected

100. American Recovery and Reinvestment Act of 2009, Pub. L. 111-5, § 7001, 123 Stat. 115, 516-20 (2009).

101. Id.

102. 12 U.S.C.A. § 5221(b)(3)(B) (Supp. 2009).

103. 12 U.S.C.A. $\S 5221(\mathrm{~b})(3)(\mathrm{C})$.

104. 12 U.S.C.A. § 5221(b)(3)(C).

105. TARP Standards for Compensation and Corporate Governance, 74 Fed. Reg. 113, 28,412 (June 15, 2009) (codified at 31 C.F.R. $\S \S 30.4,30.5,30.7$ ). 
employee's compensation complies with the compensation limitations and the changes made to their compensation packages. ${ }^{106}$ Also, section (e) requires annual shareholder voting on executive compensation plans, commonly known as a "say on pay vote"; however, this vote is non-binding on the Board of Directors. ${ }^{107}$

Congress responded to reports of TARP recipient's expenditures on luxury executive bathroom renovations and plans to purchase corporate jets by adding section (d) ${ }^{108}$ Section (d) places limitations on corporate policies and expenditures in regards to luxury expenditures. ${ }^{109}$ Luxury expenditures are those expenses the Treasury Secretary deems excessive or a luxury. ${ }^{110}$ These may include, but are not limited to, expenses for entertainment, office renovations, and aviation or other transportation. ${ }^{111}$ Corporate boards must adopt and publish an "excessive or luxury policy" to comply with these requirements. ${ }^{112}$

\section{Limitations on Incentive-Based Compensation}

The most aggressive limitations established by Congress are found in (b)(3)(D). This section prohibits TARP recipients from paying or accruing bonus or incentive-based payments while TARP obligations remain outstanding. ${ }^{113}$ In addition, disbursements of stock as compensation are limited to long-term options that cannot vest until the firms repay all obligations arising from TARP assistance. ${ }^{114}$ The value of these options cannot exceed one-third of total annual compensation. ${ }^{15}$ These provisions can apply to employees and are not necessarily limited to SEO's. ${ }^{116}$

106. $I d$.

107. 12 U.S.C.A. § 5221(e) (Supp. 2009).

108. Frank Ahrens, The Ticker_Obama: Big Wall Street Bonuses "Shameful,"WASH. Post, Jan. 29, 2009, http://voices.washingtonpost.com/economy-watch/2009/01/obama_big_wall_street_bonuses.html; David R. Sands, Bankers Deny Misusing TARP Money, WASH. TIMES, Feb. 12, 2009, available at http://www.washingtontimes.com/news/2009/feb/12/bankers-defend-record-use-bailout-funds/?page=2.

109. 12 U.S.C.A. § 5221(d) (Supp. 2009).

110. 12 U.S.C.A. § 5221(d).

111. 12 U.S.C.A. $\$ 5221$ (d).

112. TARP Standards for Compensation and Corporate Governance, 74 Fed. Reg. 113, 28,417 (June 15, 2009) (to be codified at 31 C.F.R. $\S 30.12$ ).

113. 12 U.S.C.A. § 5221(b)(3)(D) (Supp. 2009).

114. 12 U.S.C.A. $\$ 5221(\mathrm{~b})(3)(\mathrm{D})$.

115. 12 U.S.C.A. $\S 5221(\mathrm{~b})(3)(\mathrm{i})(\mathrm{I})$.

116. 12 U.S.C.A. $\S 5221(\mathrm{~b})(3)(\mathrm{D})(\mathrm{ii})(\mathrm{II}-\mathrm{IV})$. 
The applicability of compensation limitations the provision imposes is dependent on the amount of funding received. For firms who receive less than $\$ 25,000,000$ in TARP assistance, bonus limitations apply only to the most highly-compensated employee. ${ }^{117}$ For firms receiving between $\$ 25,000,000$ and $\$ 250,000,000$, compensation limitations apply to the five most highly-compensated employees. ${ }^{118}$ For firms receiving between $\$ 250,000,000$ and $\$ 500,000,000$, limitations shall apply to senior executive officers and the ten next most highly-compensated employees. ${ }^{119}$ Finally, for firms receiving over $\$ 500,000,000$, limitations shall apply to senior executive officers and the twenty next most highly-compensated employees. ${ }^{120}$ This final section of limitations would apply to every major bank that received TARP assistance in late 2008, including: Citigroup, JP Morgan Chase, Wells Fargo, Bank of America, Morgan Stanley, and Goldman Sachs. ${ }^{121}$ It would also include major auto makers General Motors and Chrysler. ${ }^{122}$ In all cases, the Secretary of the Treasury may elect to impose these conditions on a broader range of employees if the Secretary determines it serves the interest of the public. ${ }^{123}$

Although these provisions limit corporations' ability to compensate their employees, they only apply to employment agreements entered into after February 11, 2009. ${ }^{124}$ This provision allows recipients of bailout funds to make contractually agreed upon bonus payments regardless of the amount of TARP funds received. This provision accords with the Treasury Secretary's decision not to affect changes to executive compensation limitations for the firms participating in the first round of TARP. ${ }^{125}$

\section{The Executive's New Powers of Review and Revise}

The real teeth for the limitations placed on executive pay in the ARRA are found in the expansion of executive authority. Section (f) authorizes and requires the Secretary of the Treasury to review the "bonus, retention awards,

117. 12 U.S.C.A. § 5221(b)(3)(D)(ii)(I).

118. 12 U.S.C.A. § 5221(b)(3)(D)(ii)(II).

119. 12 U.S.C.A. § 5221(b)(3)(D)(ii)(III).

120. 12 U.S.C.A. § 5221(b)(3)(D)(ii)(IV)

121. CONGRESSIONAL Budget OFFICE, supra note 75.

122. $I d$.

123. 12 U.S.C.A. $\S 5221(\mathrm{~b})(3)(\mathrm{D})(\mathrm{ii})(\mathrm{II}-\mathrm{IV})$.

124. 12 U.S.C.A. $\$ 5221(\mathrm{~b})(3)(\mathrm{D})(\mathrm{iii})$.

125. U.S. TREASURY DEP'T, supra note 76 (“These new standards will not apply retroactively to existing investments or to programs already announced such as the Capital Purchase Program and the Term Asset-Backed Securities Loan Facility.”); see also 31 C.F.R. § 30.17 (2009). 
and other compensation paid to senior executive officers and the next twenty most highly-compensated employees of each entity receiving TARP assistance" prior to the enactment of ARRA. ${ }^{126}$ Should the Secretary deem any such payments contrary to public interest or inconsistent with the premise of TARP, he must negotiate with the TARP recipient and employee for reimbursement of the compensation or bonus to the Federal Government. ${ }^{127}$

To comply with section (f), the Treasury created "The Office of the Special Master for TARP Executive Compensation," also known as "the Pay Czar," and appointed Kenneth R. Feinberg as the first American Pay Czar. Mr. Feinberg must review all bonus payments paid by TARP recipients before February 17, 2009. ${ }^{128}$ Should he determine the payments were contrary to the policy of section 111 of the ARRA, Mr. Feinberg must negotiate with the TARP recipient and employee for reimbursement of the payment to the U.S. Government. ${ }^{129}$

Mr. Feinberg also has the duty to review and approve the compensation plans for SEOs and the 100 most highly compensated employees at all corporations receiving "exceptional assistance" or $\$ 500,000,000$ in assistance. ${ }^{130} \mathrm{He}$ has the authority to disapprove compensation arrangements that he deems excessive, inappropriate, or unsound. ${ }^{131}$ Corporations are obligated to produce all documentation the Special Master requires to complete the compensation plan reviews. ${ }^{132}$

The Pay Czar, backed by the executive, appears committed to reining in excessive executive compensation. Mr. Feinberg has asserted his authority and intention to review and revise previous bonus payouts and current compensation packages of all TARP recipients despite the limiting statutory provision and the Treasury Department's earlier claim that compensation limitations will not apply to agreements entered into prior to February 11, 2009. ${ }^{133}$ According to the Pay Czar, his review will include corporations that

126. 12 U.S.C.A. § 5221(f)(1).

127. 12 U.S.C.A. $\$ 5221(\mathrm{f})(2)$.

128. 31 C.F.R. $\S 30.16(\mathrm{a})(2)(2009)$.

129. 12 U.S.C.A. § 5221(e) (Supp. 2009).

130. Treasury Department, "Interim Final Rule for TARP Standards for Compensation and Corporate Governance," June 10, 2009, http://www.ustreas.gov/press/releases/tg165.htm. As of June 10, 2009, corporations that received "exceptional assistance" include Citigroup, Bank of America, AIG, Chrysler, GM, GMAC, and Chrysler Financial.

131. 31 C.F.R. $\S 30.16(3)(2009)$.

132. 31 C.F.R. $\$ 30.16(3)(2009)$.

133. 31 C.F.R. § 30.17 (effective June 15, 2009); see also 12 U.S.C.A. § 5221(D)(iii) (Supp. 2009). 
no longer have TARP obligations outstanding, e.g. Goldman Sachs and J.P. Morgan. ${ }^{134}$

\section{Overall Effect on TARP Recipient Corporations}

Some critics of the amendments argue the provisions fall short of effectively reining in the excesses of corporate compensation. ${ }^{135}$ One potential loophole would be for compensation committees to simply raise base salaries of corporate executives. Although the amended section 111 places strict limitations on bonus payments, it does not place caps on all forms of compensation. Despite President Obama's plan to cap all compensation at $\$ 500,000$, the ARRA in no way restricts or limits salary payments. Typically, corporations take advantage of section $162(\mathrm{~m})$ of the Tax Code, which allows corporations to deduct payments to employees, by paying executives salaries under $\$ 1,000,000$; the vast majority of compensation comes in the form of incentive-based pay. However EESA amended section 162(m), limiting salary expenditures for TARP recipients to $\$ 500,000 .{ }^{136}$ Compensation committees could choose to forgo tax benefits. By increasing an executive's fixed salary, corporations could maintain the value of corporate compensation packages. If a committee decided to evade compensation limitations, it would result in greater tax revenue for the federal government.

Nevertheless, the limitations on executive pay implemented in the ARRA are drastically different from those of the EESA. Unlike EESA regulations, the limitations imposed by the ARRA will significantly change how TARP participants compensate their employees. ${ }^{137}$ One of the most dramatic shifts are the potential limitations of (b)(3)(D). Depending on the regulations the Treasury adopts, these limitations have the potential for capping compensation on all employees. ${ }^{138}$ Most importantly, the Pay Czar may force TARP

134. Steve Eder, U.S. pay czar says he can claw back exec compensation, REUTERS, Aug. 17, 2009, http://www.reuters.com/article/newsOne/idUSTRE57G0E820090817?pageNumber=1\&virtualBrandCh annel $=0$.

135. Tse, supra note 69 .

136. I.R.C. $\S 162(\mathrm{~m})(5)$ (Supp. 2009)

137. I.R.C. $\S 162(\mathrm{~m})(5)$

138. If you restrict compensation payments on the 20 most highly-compensated employees, presumably that group will no longer be the 20 most highly-compensated employees because the next 20 most highly compensated employees will take their place. If in turn their compensation payments are capped, the regulations will effectively set a cap on payments at the same level of the original 20 most highly-compensated employees. See Mark Maremont \& Joann S. Lublin, Limits on Pay Left Unclear in New Law, Wall ST. J., Feb. 18, 2009, at A4, available at http://online.wsj.com/article/SB12349 1033872703471.html. 
participants to recoup bonus payments and change their current compensation packages.

\title{
PART III-CORPORATE DUTY TO PARTICIPATE IN TARP
}

\begin{abstract}
The chief executives of the nine largest banks in the United States trooped into a gilded conference room at the Treasury Department at 3 p.m. Monday. To their astonishment, they were each handed a one-page document that said they agreed to sell shares to the government, then Treasury Secretary Henry M. Paulson Jr. said they must sign it before they left.
\end{abstract}

"It was a take it or take it offer," said one person who was briefed on the meeting, speaking on condition of anonymity because the discussions were private. "Everyone knew there was only one answer."- The New York Times ${ }^{139}$

After over three hours of deliberation, all nine institutions capitulated to Secretary Paulson's demand to participate in TARP. The choice to acquiesce did not come easy for every CEO. The decision to participate in TARP puts corporate directors and executives in a unique position. As noted, the aid comes with many strings attached, including: increased compliance costs, forcing corporations to make substantial adjustments in their business plans and corporate structure, and subjects Board of Director decisions to oversight by the Treasury Secretary and Pay Czar that carry the potential for corporate and federal claw-back of misused corporate funds. The ARRA provisions are also potentially damaging to shareholders, because corporations must issue preferred shares and warrants for common stock in exchange for TARP aid, thereby diluting each shareholder's ownership. Most importantly to the discussion at hand, a vote to obtain TARP assistance by a director is in effect a vote to lower their own pay.

As Secretary Paulson predicted during the negotiations of EESA, restrictions on executive compensation endangered the participation of financial institutions. ${ }^{140}$ During the meeting, Richard Kovacevich, CEO of Wells Fargo, fought against Paulson's proposal by raising concerns over the restrictions on executive compensation. ${ }^{141}$ At the time, Mr. Kovacevich's severance entitlements totaled nearly $\$ 200,000,000 .{ }^{142}$ Kenneth Lewis, CEO of Bank of America, responded to concerns over the restrictions by urging

139. Mark Landler \& Eric Dash, Drama Behind a Banking Deal, N.Y. TiMES, Oct. 15, 2008, available at http:/query.nytimes.com/gst/fullpage.html?res=9401EEDF1F39F936A25753C1A96E9C8B63.

140. Stout, supra note 1.

141. Landler \& Dash, supra note 139.

142. Id. 
other executives to participate. He reportedly remarked, [if we let executive compensation block the bailout we are out of our minds. ${ }^{143}$

Assuming Secretary Paulson was correct in his assertion that some firms would not have agreed to participate in TARP had stricter limitations been placed on executive compensation, congressional action to initially set lower standards in order to encourage participation and then change the standards after the fact amounts to a bait and switch. Had the nine CEOs known about the strict restrictions that would be ultimately placed on corporations and compensation packages, perhaps Mr. Kovacevich's position would have won the day. But was the political posturing really necessary? In other words, could executives decide not to participate solely because of restrictions placed on their own compensation?

A board's decision not to participate in TARP would most likely withstand a challenge brought by a shareholder or other interested party in a court of law. ${ }^{144}$ Generally speaking, a corporate board has "the authority and broad discretion to make executive compensation decisions." 145 This position is supported by state corporate statutes, including Delaware's, and by the Model Business Corporation Act of $1984 .{ }^{146}$ As such, decisions pertaining to executive compensation will generally be afforded the protection of the business judgment rule. ${ }^{147}$

In order to overcome the business judgment rule presumption, a challenger would need to show "the directors are interested or lack independence relative to the decision." ${ }^{148}$ Directors who have an interest in a transaction potentially violate their duty of loyalty owed to the corporation and its shareholders. The duty of loyalty "mandates that the best interest of the corporation and its shareholders take precedence over any interest possessed by a director, officer or controlling shareholder and not shared by the stockholders generally." "149

143. $I d$.

144. Although interested parties are typically limited to shareholders and individuals who can sue on behalf of the corporation, some courts have found that creditors are interested parties once the corporation enters the zone of insolvency. The ability of creditors to sue to affect corporate decision-making is not contemplated by this note.

145. In re Citigroup Inc. S'holder Derivative, 964 A.2d 106, 138 (Del. Ch. 2009).

146. See Del. Code ANN. tit. 8, §§ 122(5), (15) (2009); Model Business Corporation ACT $\S \S 8.01$ (c)(iii), 8.11 (2005). See also Tracy Scott Johnson, Pay for Performance: Corporate Executive Compensation in the 1990s, 20 DEL. J. CORP. L. 183, 220-21 (1995).

147. See Harber v. Bell, 465 A.2d 353 (Del. Ch. 1983) (holding that the business judgment rule generally protects compensation decisions by board of directors); Johnson, supra note 146 at 220-21.

148. Brehm v. Eisner, 746 A.2d 244, 264 n.66 (Del. 2000).

149. In re Walt Disney Co. Derivative Litig., 907 A.2d 693, 751 (Del. Ch. 2005) (citing Pogostin v. 
On its face, the decision not to participate in TARP because of restrictions placed on compensation appears to be a self-interested transaction. Directors are placed in a position where ratification of a transaction could damage their interest (that is, their interest in receiving compensation) while rejection would place their interests, not shared by the stockholders, over those of the corporation. Take, for example, Mr. Kovacevich who was entitled to almost $\$ 200,000,000$ in severance payments when he decided Wells Fargo would participate in TARP. In 2007, Mr. Kovacevich's cash compensation was $\$ 6,695,000$, of which only $\$ 995,000$ was salary; the remainder of his compensation was bonus payments. ${ }^{150}$ Under the executive compensation rules of ARRA, Mr. Kovacevich stands to have a significant reduction in income, assuming his compensation plan does not change. ${ }^{151}$ Furthermore, if Mr. Kovacevich were to leave Wells Fargo, Wells Fargo would not legally be permitted to make a substantial portion of those payments. ${ }^{152}$

The transaction boils down to a choice between serving the corporation's interests or serving his own interests. By agreeing to participate in TARP, Mr. Kovacevich would be effectively limiting his compensation by over $80 \%$, while, arguably, increasing the financial well-being of his institution. ${ }^{153}$ By refusing to participate, Mr. Kovacevich compensation would remain unchanged. On the other hand, Wells Fargo would have missed out on a substantial opportunity for capital infusion. The duty of loyalty seemingly mandates Mr. Kovacevich to opt to participate in TARP. ${ }^{154}$

Despite the clear self-interest in the above transaction, such a decision would still likely withstand a legal challenge, and may even be afforded the protection of the business judgment rule. ${ }^{155}$ All states, such as Delaware, provide a safe harbor for corporate boards dealing with self-interest in

Rice, 480 A.2d 619, 624 (Del. 1984)).

150. Executive Profile: Richard M. Kovacevich, BuSINESSWEEK, http://investing.businessweek.com/ businessweek/research/stocks/people/person.asp?personId=292897\&capId=292891\&previousCapId=29 2891\&previousTitle $=$ Wells\%20Fargo\%20\%26\%20Company (last visited Mar. 15, 2009) [hereinafter Executive Profile].

151. For argument's sake, this section assumes that section (D)(iii) provisions exempting agreements entered into prior to February 11, 2009 from limitations does not apply.

152. 12 U.S.C.A. § 5221(a)(2) (Supp. 2009).

153. Of his 2007 compensation, $\$ 570,000,000$ would be considered "bonus." As such, Wells Fargo would not be permitted to make that payment. They would be limited to long-term stock options no greater than one-third his annual salary. His total compensation would be approximately $\$ 1,300,000$. See 12 U.S.C.A. § 5221(b)(3)(D) (Supp. 2009).

154. Executive Profile, supra note 150.

155. See Eric G. Orlinsky, Corporate Opportunity Doctrine and Interested Director Transactions: A Framework for Analysis in an Attempt to Restore Predictability, 24 DEL. J. CORP. L. 451, 522 (1999). 
transactions. ${ }^{156}$ Assuming the decision to not participate in TARP was reached with due care, a safe harbor rule could provide the board's decision with business judgment rule protection. ${ }^{157}$

Should a court decide not to give deference to the board's decision under the protection of the business judgment rule, the court would then evaluate the transactions ultimate fairness to the corporation. A court would likely ratify the board's decision. Although a corporate board has a significant self-interest in rejecting TARP funds, accepting funds places significant burdens on financial institutions. These burdens include significant government intrusion in to the corporate board room, increased costs associated with dividend payments on the preferred shares financial institutions must pay to the government as owner of these shares, and the potential for dilution of shareholder ownership if the warrants for common shares were exercised. ${ }^{158}$

Dividend payments alone are likely enough to justify a board's decision to reject TARP funds. Take for example Wells Fargo, discussed above. By rejecting TARP funds. Mr. Kovecevich would be preserving for himself $\$ 5.7$ million in compensation. Although this compensation would come from corporate coffers, it pales in comparison to the costs levied in dividend payments that accompany accepting the funds. On February 2, 2009, Wells Fargo paid its first dividend to the U.S. government; the dividend required the corporation to pay the government over $\$ 370$ million. ${ }^{159}$ This payment represents only a quarter of the total dividends Wells Fargo is required to pay for 2009. ${ }^{160}$

156. Del. CODE ANN. tit. 8, § 144 (2009).

157. If a corporate executive acted unilaterally in his/her rejection of TARP, that action could potentially violate a number of corporate duties. See generally Brehm v. Eisner, 746 A.2d 244 (Del. 2000); Smith v. Van Gorkem, 488 A.2d 858 (Del. 1985).

158. See Ari Levy, Wells Fargo Assails TARP, Calls Stress Test “Asinine,” BloomBerg, Mar. 16, 2009, http://www.bloomberg.com/apps/news?pid=20601087\&sid=aWWd8s37rrE0\&refer=home (last visited Mar. 23, 2009); Elizabeth Hester, Citigroup, Bank of America, JPMorgan Criticize Limits, BLOOMBERG, Mar. 21，2009， http://www.bloomberg.com/apps/news?pid=20601087\&sid=am3Q 20T0S44\&refer=worldwide (last visited Mar. 23, 2009).

159. Colin Barr, Wells Fargo Paying $\$ 371.5$ Million to Government, CNNMONEY, http:// money.cnn.com/2009/02/02/news/wells.dividend.fortune/index.htm (last visited Mar. 23, 2009).

160. CONGRESSIONAL BUdGet OFFICE, supra note 75. 


\section{PART IV—POSTURING FOR NOTHING}

How do you give a bonus to someone for having failed so badly as many of these people did?

$$
\text { - Representative Barney Frank }{ }^{161}
$$

Despite a corporate board's prerogative to reject bailout funds, all of the systematically significant institutions agreed to accept the capital infusion from TARP. Participation in the program was considerable. In that regard, the legislators were effective. As a result, the feared catastrophic collapse may have been avoided. As of the time of publication in Spring 2010, the U.S. economy appears to be on the verge of recovery. There are no soup lines.

Similarly, more time is needed to evaluate how effective Congress was in protecting taxpayer investments via limitations on compensation. In the first round of the bailout legislative efforts were nominal at best. Any institution that participated in a transaction under the first phase of the bailout entered into an agreement with the Treasury Department. ${ }^{162}$ These various agreements of individual institutions are substantively quite similar. As part of each agreement, each institution was required to recognize and take the necessary steps to comply with the executive compensation rules promulgated by the Treasury as authorized by the EESA. Although taxpayer outrage over the bonus payments made by bailed out corporations may be legitimate, in no way did those firms breach their legal commitments entered into with the Treasury Department.

Despite the lawfulness of the payments, the taxpayers may still receive the protection they demand. The limitations passed in the ARRA could severely constrain compensation packages. Moreover, portions of the bonuses already paid by TARP recipients may have to be returned to the Federal Government. The extent to which the Treasury Department, and Pay Czar Kenneth Feinberg, will exercise their authority remain uncertain. ${ }^{163}$

Effectiveness aside, the Congressional efforts to address the two problems of economic stabilization and excessive compensation could have been

161. Hard Times, But Big Wall Street Bonuses, The Early Show, CBS News, Nov. 12, 2008, available at $\mathrm{http} / /$ www.cbsnews.com/stories/2008/11/12/earlyshow/main4595179.shtml.

162. See Department of The Treasury, http://www.financialstability.gov/roadtostability/ (follow "Capital Purchase Program" hyperlink) (last visited Sept. 17, 2009); see also U.S. Department of the Treasury, http://www.financialstability.gov/roadtostability/ (follow "Capital Purchase Program" hyperlink, then follow "Fact Sheet: Capital Purchase Program" hyperlink) (last visited Sept. 17, 2009).

163. Steve Eder \& Karey Wutkowski, Wall Street Ponders Pay Czar's Move on Clawbacks, REUTERS, available at $\mathrm{http}: / /$ www.reuters.com/article/ousiv/idUSTRE57I68F20090819. 
handled better. By using the bailout legislation to address executive compensation, Congress tied its own hands. It was forced to legislate ineffective limitations in order to promote participation in the scheme. Once the populist rage boiled over, Congress responded by placing new regulations on firms that agreed to participate in TARP under the rules enacted in the ESSA. For political leaders to attack corporations and their executives for making bonus payments that complied with the rules those same politicians crafted was beyond hypocritical, it was repugnant. ${ }^{164}$

Had Congress separated its solutions to the two distinct problems, it could have better used the political capital to achieve real gains rather than wasting it on encouraging participation in the TARP scheme that achieved only nominal compensation reform. For example, Congress could have compelled banks accepting assistance to increase lending. Moreover, the limitations on executive pay are limited to a discrete sector of the economy. By addressing excessive compensation in a separate Act of Congress, reform could have been more widespread and lasting. Rather than lumping the solutions to many problems together in one massive bill, perhaps its time for change. Next time, Congress should concentrate on solving one crisis at a time.

164. See Rich Edson, Amid AIG Furor, Dodd Tries to Undo Bonus Protections in the Dodd Amendment Rules, FOXBUSINESS, Mar. 17, 2009, http://www.foxbusiness.com/story/markets/industries/ finance/dodd-cracks-aig---time (last visited Mar. 23, 2009). 